\title{
CONSTANT MURLEY SCORE ON PATIENTS POST SUPRASPINATUS RECONSTRUCTION WITH MEMBRANE AMNION COMPOSITE AND FAT TISSUE ALLOGENIC MESENCHYMAL STEM CELL AUGMENTATION
}

\author{
Heri Suroto ${ }^{1}$, Bayu Antara Hadi ${ }^{*}$, Goklas Ridwan Ricardo Gultom ${ }^{2}$ \\ ${ }^{1}$ Staff of Orthopaedic and Traumatology Department, Faculty of Medicine, Universitas \\ Airlangga, Dr Soetomo General Hospital, Surabaya \\ ${ }^{2}$ Resident of Orthopaedic and Traumatology Department, Faculty of Medicine, Universitas \\ Airlangga, Dr Soetomo General Hospital, Surabaya \\ *Corresponding Author: Bayu Antara Hadi, Resident of Orthopaedic and Traumatology \\ Department, Faculty of Medicine, Universitas Airlangga, Jl. Mayjen Prof. Dr. Moestopo 6-8, \\ Surabaya \\ E-mail: bayuantarahadi@gmail.com
}

\begin{abstract}
ABSTRAK
Latar Belakang: Robekan rotator cuff merupakan hal tersering terjadi pada kasus non trauma ekstremitas atas kelompok usia lebih dari 50 tahun. Angka kejadian saat ini belum dapat menggambarkan. Pendekatan terbaru untuk penyembuhan rotator cuff syndrome melalui regenerasi tendon seperti injeksi lokal mesenkimal stem cell dan faktor pertumbuhan atau rekayasa jaringan telah dikembangkan.

Metode Penelitian: Studi komparasi retrospektif dari 15 pasien postreparasi supraspinatus selama lebih 4 bulan di RSUD Dr Soetomo. Pasien dibagi menjadi kelompok reparasi supraspinatus dan kelompok reparasi dengan diaugmentasi komposit amnion membrane dan sel punca mesenkimal alogenik. Hasilnya dievaluasi menggunakan constant murley score.

Hasil: Rerata nilai nyeri pasien reparasi supraspinatus yang diaugmentasi membran amnion dan sel punca mesenkimal dan yang tanpa augmentasi adalah 15 dan 13,7 ( $\mathrm{p}=0,036)$. Rerata nilai aktivitas harian yang diaugmentasi dan yang tanpa augmentasi adalah 20 dan 17 $(\mathrm{p}=0,037)$. Rerata nilai gerakan fleksi yang diaugmentasi dan yang tanpa augmentasi adalah 10 dan $8,6(\mathrm{p}=0,114)$. Rerata nilai lateral elevasi yang diaugmentasi dan yang tanpa augmentasi adalah 10 dan $8,6(\mathrm{p}=0,114)$. Rerata nilai eksternal rotasi yang diaugmentasi dan yang tanpa augmentasi adalah 9,6 dan 7,2 ( $\mathrm{p}=0,004)$. Rerata nilai internal rotasi yang diaugmentasi dan tanpa augmentasi adalah 9,2 dan 7,2 ( $\mathrm{p}=0,012)$.

Kesimpulan: Pain score, ADL score, external rotation score, dan internal rotation score pada constant murley score dalam pada kelompok dengan penambahan amniotic membrane dan mesenchymal stem cell secara signifikan lebih baik daripada kelompok dengan supraspinatus repair saja, namun tidak signifikan pada flexion score dan lateral elevation score.
\end{abstract}

Kata Kunci: reparasi supraspinatus, sel punca mesenkimal, membran amnion

\begin{abstract}
Background: Rotator cuff tears are the most common cases in nontrauma upper extremities in group patient more than 50 years old. Incidence on rotator cuff can't show the real population. New Approaches healing rotator cuff syndrome is tendon regeneration like mesenchymal stem cell injection and growth factor or tissue engineering that has been developed.

Methods: Retrospective comparation study of 15 postsupraspinatus reparation patients who has been treated for more than 4 months at the Dr. Soetomo general hospital. Patients is divided into group undergone supraspinatus reparation and patient supraspinatus reparation with augmented by membrane amnion composite and mesenchymal stem cell. Its' functional results were evaluated using constant murley score.
\end{abstract}


Results: Pain score average on supraspinatus reparation patients which augmented by membrane amnion and mesenchymal stem cell and those without augmentation is 15 and 13.7 $(\mathrm{p}=0.036)$. Daily activity score average on patients with and without augmentation are 20 and $17(\mathrm{p}=0.037)$. Flexion score average on patients with and without augmentation are 10 and 8.6 $(\mathrm{p}=0.114)$. External rotation score average on patients with and without augmentation are 9.6 and $7.2(\mathrm{p}=0.004)$. Internal rotation score average on patients with and without augmentation are 9.2 and $7.2(\mathrm{p}=0.012)$.

Conclusion: The constant murley score pain score, ADL score, external rotation score, and internal rotation score in the group with the addition of amniotic membrane and mesenchymal stem cells were significantly better than the group with supraspinatus repair only, but not significantly on the flexion score and lateral elevation score components.

Keywords: supraspinatus reparation, mesenchymal stem cell, membrane amnion

\section{PENDAHULUAN}

Cedera rotator cuff adalah kelainan patologis yang ditandai dengan robekan sebagian dan/atau total pada kelompok otot dan tendon di sendi bahu, tepatnya sendi glenohumeral. Prevalensi Cedera rotator cuff meningkat dengan bertambahnya usia.

Sebanyak $4 \%$ pasien merupakan kelompok berusia $<40$ tahun dan bersifat asimtomatik dan $54 \%$ pasien berusia $\geq 60$ tahun. Cedera otot rotator cuff dapat terjadi karena cedera traumatis. Cedera ini bersifat kronik dan progresif. Gejala klinisnya berupa nyeri dan berkurangnya gerakan sendi bahu serta gejala awal osteoartritis. Prosedur pembedahan memungkinkan adanya lesi ulangan sekitar 50\%. Hal tersebut disebabkan kerusakan tendon supraspinatus (SP) di tempat insersinya yang sulit untuk dikembalikan. ${ }^{1-4}$

Oleh karena itu, diperlukan pendekatan baru yang dapat meningkatkan proses penyembuhan. Percepatan penyembuhan dapat dicapai dengan pemberian injeksi lokal mesenchymal stem cells (MSCs). Kemudian dilakukan evaluasi menggunakan skor Constant Murley, sebagai skor penilaian fungsional untuk mengetahui efektivitas penambahan mesenchymal stem cell. Kami berpendapat bahwa pemberian stem cell ini dapat memberikan hasil fungsional yang lebih baik. $^{5-7}$

\section{METODOLOGI PENELITIAN}

Penelitian ini merupakan studi kohort retrospektif. Sampel penelitian adalah pasien ruptur supraspinatus yang telah dilakukan operasi di RSUD Dr. Soetomo. Sampel dibagi menjadi 2 kelompok yaitu dengan dan tanpa pemberian amnion membrane (AM) dan Allogenic MSC of fat tissue. Penilaian skor Constant Murley dilakukan setelah 4 bulan terapi di RSUD Dr. Soetomo pada pasien kontrol poli maupun kunjungan rumah pasien (home visite). Penilaian skor Constant Murley meliputi nyeri, aktivitas harian, dan gerakan bahu: fleksi, lateral elevasi, eksternal rotasi, internal rotasi. ${ }^{8-10}$ 
Pada penelitian ini didapatkan distribusi data tidak normal pada masing-masing variabel $(\mathrm{p}<0,005)$ sehingga uji non parametrik yang digunakan adalah Mann-Whitney.

\section{HASIL DAN PEMBAHASAN}

Terdapat 15 sampel, 5 sampel diberikan amnion membrane dan mesenchymal stem cell of fat dan 10 sampel yang hanya dilakukan operasi supraspintus reparation saja. Pasien berjenis kelamin laki-laki 4 orang $(26,7 \%)$ dan berjenis kelamin perempuan 11 orang $(73,3 \%)$ dengan rerata umur 51,13 \pm 7,17 tahun seperti yang tertera pada Tabel 1 .

Hasil analisis pada rata-rata nilai flexion score, ADL score, internal rotation score, dan external rotation score pada pasien yang menjalani supraspinatus reparation dengan penambahan amniotic membrane dan mesenchymal stem cell mempunyai nilai rata-rata yang lebih baik secara signifikan dibandingkan pasien yang tanpa diberikan penambahan stem cell. ( $\mathrm{p}_{\text {pain }}$ $=0,037 ; \mathrm{p}_{\text {adl }}=0,034 ; p_{\text {internal rotation }}=0,002$; pexternal rotation $=0,011$ )

Pada penelitian ini didapatkan distribusi data tidak normal pada masingmasing variabel $(p<0,005)$, sehingga peneliti menggunakan uji non parametrik, MannWhitney.
Tabel 1. Karakteristik pasien yang menjalani operasi

\begin{tabular}{lc}
\hline \multicolumn{1}{c}{ Karakteristik } & Jumlah (\%) \\
\hline Jenis Kelamin & \\
Laki-laki & $4(26,7 \%)$ \\
Perempuan & $75(73,3 \%)$ \\
Usia (tahun) & $51,13 \pm 7,17$ \\
$\begin{array}{l}\text { Usia maksimum } \\
\text { (tahun) }\end{array}$ & 61 \\
$\begin{array}{l}\text { Usia minimum } \\
\text { (tahun) }\end{array}$ & 36 \\
$\begin{array}{l}\text { Follow up (bulan) } \\
\text { Follow up } \\
\text { maksimum (bulan) }\end{array}$ & 140 \\
$\begin{array}{l}\text { Follow up minimum } \\
\text { (bulan) }\end{array}$ & 140 \\
\hline
\end{tabular}

Pada kelompok supraspinatus reparation yang ditambahkan amnion membrane dan mesenchymal stem cell mempunyai hasil Pain score dengan ratarata 15,00;ADL score dengan rata-rata 20,00 tampak pada Tabel 4; Flexion score dengan rata-rata 10,00 tampak pada Tabel 5; Lateral elevation score dengan rata-rata 10,00 tampak pada Tabel 6; External rotation score dengan rata-rata 9,60 tampak pada Tabel 7; Internal rotation score dengan ratarata 9,20 tampak pada Tabel 8. Pada kelompok Supraspinatus reparation saja mempunyai hasil Pain score dengan rata rata-rata 13,80 tampak pada Tabel 3; $A D L$ score dengan rata-rata 17,40 sepeti tampak pada Tabel 4; Flexion score dengan rata-rata 
9,00 tampak pada tabel tabel 5; Lateral elevation score dengan rata-rata 8,60 tampak pada Tabel 6; External rotation score dengan rata-rata 7,60 tampak pada tabel 7; Internal rotation score dengan rata-rata 7,60 tampak pada Tabel 8. Hasil score rata-rata dapat dilihat pada Tabel 2 berikut.

Tabel 2. Rata-rata Hasil pemeriksaan Evaluasi Constant Murley Score pada dua kelompok

\begin{tabular}{lcc}
\hline $\begin{array}{l}\text { Constant } \\
\text { Murley } \\
\text { Score }\end{array}$ & $\begin{array}{c}\text { SR + AM + } \\
\text { MSC }\end{array}$ & SR \\
\hline Pain Score & 15,00 & 13,80 \\
ADL Score & 20,00 & 17,40 \\
$\begin{array}{l}\text { Flexion } \\
\text { Score }\end{array}$ & 10,00 & 9,00 \\
$\begin{array}{l}\text { Lateral } \\
\text { Elevation }\end{array}$ & 10,00 & \\
Score & & \\
$\begin{array}{l}\text { External } \\
\text { Rotation } \\
\text { Score }\end{array}$ & 9,60 & \\
$\begin{array}{l}\text { Internal } \\
\text { Rotation }\end{array}$ & 9,20 & 7,60 \\
Score & & \\
\hline
\end{tabular}

Setiap hasil evaluasi menggunakan uji Mann-Whitney. Pada Pain score, terdapat perbedaan nilai Pain score yang signifikan secara statistik antara kelompok supraspinatus reparation yang diberikan amnion membrane dan mesenchymal stem cell dibandingkan kelompok yang dilakukan Supraspinatus reparation saja $(\mathrm{p}=0,037)$.
Tabel 3. Uji Hipotesis Pain score

\begin{tabular}{lcc}
\hline & Median & Nilai p \\
\hline $\begin{array}{l}\text { Kelompok } \\
\text { SR+AM+MSC } \\
(\mathrm{n}=5)\end{array}$ & $\begin{array}{c}15,00(15,00- \\
\text { 15,00) }\end{array}$ & 0,037 \\
$\begin{array}{l}\text { Kelompok SR } \\
(\mathrm{n}=10)\end{array}$ & $\begin{array}{c}14,00(11,00- \\
\end{array}$ & $15,00)$
\end{tabular}

*Uji Mann-Whitney; Ranking rerata SR+AM+MSC 11,00; Ranking rerata SR 6,50

Pada $A D L$ score, terdapat perbedaan nilai $A D L$ score yang signifikan secara statistik antara kelompok Supraspinatus reparation yang diberikan membran amnion dan mesenchymal stem cell dibandingkan kelompok yang dilakukan Supraspinatus reparation saja $(\mathrm{p}=0,034)$ seperti yang terlihat pada Tabel 4.

Tabel 4. Uji Hipotesis ADL score

\begin{tabular}{ccc}
\hline & $\begin{array}{c}\text { Median } \\
\text { (Minimum- } \\
\end{array}$ & $\begin{array}{c}\text { Nilai } \\
\text { Maksimum) }\end{array}$ \\
& \\
\hline Kelompok & $20,00(20,00-$ & 0,034 \\
$\begin{array}{c}\text { SR+AM+MSC } \\
(\mathrm{n}=5)\end{array}$ & $20,00)$ & \\
& &
\end{tabular}

$\begin{array}{cc}\text { Kelompok SR } & 17,00(9,00- \\ (\mathrm{n}=10) & 20,00)\end{array}$

*Uji Mann-Whitney; Ranking rerata $\mathrm{SR}+\mathrm{AM}+\mathrm{MSC}$ 11,00; Ranking rerata SR 6,50

Flexion score tidak terdapat perbedaan yang signifikan secara statistik antara kelompok Supraspinatus reparation yang diberikan Amnion Membrane dan Mesenchymal Stem Cell dibandingkan 
kelompok yang dilakukan Supraspinatus reparation saja $(\mathrm{p}=0,301)$.

Tabel 5. Uji hipotesis flexion score

\begin{tabular}{ccc}
\hline & Median & Nilai p \\
\hline Kelompok & $10,00(10,00-$ & 0,301 \\
SR+AM+ & $10,00)$ & \\
MSC & & \\
$(\mathrm{n}=5)$ & &
\end{tabular}

Kelompok $\quad 9,00(2,00-$

$\mathrm{SR}(\mathrm{n}=10) \quad 10,00)$

*Uji Mann-Whitney; Ranking rerata SR+AM+MSC 9,00; Ranking rerata SR 7,50

Data Lateral Elevation Score menggunakan Shapiro-Wilk menunjukkan data tidak terdistribusi normal $(\mathrm{p}<0,05)$. Kemudian pengujian dilanjutkan dengan menggunakan uji Mann-Whitney.

Pada Lateral Elevation score, tidak terdapat perbedaan nilai Lateral Elevation score yang signifikan secara statistik antara kelompok Supraspinatus reparation yang diberikan Amnion Membrane dan Mesenchymal Stem Cell dibandingkan kelompok yang dilakukan Supraspinatus reparation saja $(\mathrm{p}=0,114)$.

Tabel 6. Uji hipotesis Lateral Elevation score

\begin{tabular}{ccc}
\hline & Median & Nilai p \\
\hline Kelompok & 10,00 & 0,114 \\
SR+AM+MS & $(10,00-$ & \\
C $(n=5)$ & $10,00)$ &
\end{tabular}

Kelompok SR $10,00(2,00-$ $(n=10) \quad 10,00)$
*Uji Mann-Whitney; Ranking rerata SR+AM+MSC 10,00; Ranking rerata SR 7,00

Data External Rotation Score yang tersaji kemudian diuji distribusinya menggunakan Shapiro-Wilk. Hasilnya menunjukkan bahwa data tidak terdistribusi normal $(\mathrm{p}<0,05)$. Kemudian dievaluasi setiap hasilnya menggunakan MannWhitney.

Pada External Rotation score, terdapat perbedaan nilai External Rotation score yang signifikan secara statistik antara kelompok Supraspinatus reparation yang diberikan Amnion Membrane dan Mesenchymal Stem Cell dibandingkan kelompok yang dilakukan Supraspinatus reparation saja $(\mathrm{p}=0,002)$.

Tabel 7. Uji hipotesis External Rotation score

\begin{tabular}{ccc}
\hline & Median & Nilai p \\
\hline Kelompok & $10,00(8,00-$ & 0,002 \\
SR+AM+MS & $10,00)$ & \\
C $(n=5)$ & &
\end{tabular}

Kelompok SR $\quad 8,00(4,00-$ $(\mathrm{n}=10) \quad 8,00)$

*Uji Mann-Whitney; Ranking rerata SR+AM+MSC 12,10; Ranking rerata SR 5,95

Data Internal Rotation Score yang tersaji diuji distribusi normal menggunakan Shapiro-Wilk menunjukkan data tidak terdistribusi normal. $(\mathrm{p}=<0,05) \mathrm{Uji}$ hipotesis dilakukan pada setiap hasil evaluasi menggunakan uji Mann-Whitney. 
Pada Internal Rotation score, terdapat perbedaan nilai Internal Rotation score yang signifikan secara statistik antara kelompok Supraspinatus reparation yang diberikan Amnion Membrane dan Mesenchymal Stem Cell dibandingkan kelompok yang dilakukan Supraspinatus reparation saja. $(\mathrm{p}=0,011)$

Tabel 8. Uji hipotesis Internal Rotation score

\begin{tabular}{ccc}
\hline & $\begin{array}{c}\text { Median } \\
\text { (Minimum- } \\
\text { Maksimum) }\end{array}$ & Nilai p \\
\hline Kelompok & 10,00 & 0,011 \\
SR+AM+MS & $(8,00-$ & \\
C (n=5) & $10,00)$ &
\end{tabular}

Kelompok SR $8,00(4,00-$ $(\mathrm{n}=10) \quad 8,00)$

*Uji Mann-Whitney; Ranking rerata SR+AM+MSC 11,20; Ranking rerata SR 6,40

Mesenchymal stem cells (MSC) dapat berdiferensiasi menjadi jaringan mesodermal yang berbeda dan memiliki parakrin yang kuat, anti-inflamasi, imunoregulatori dan potensi angiogenik. Terapi sel induk merupakan terapi yang berpotensi efektif untuk meningkatkan penyembuhan rotator cuff. Hasil penggunaan MSC autologus dari hewan terbukti memiliki sifat penyembuhan yang lebih baik, meningkatkan jumlah pembentukan fibrokartilago dan meningkatkan orientasi serat fibrokartilago dengan respon imunologi yang lebih sedikit dan mengurangi infiltrasi limfosit. ${ }^{5,11-13}$

Menurut Yamamoto et al, masalah utama kegagalan dalam perbaikan rotator cuff disebabkan oleh factor biologis, karena zona transisi fibro-cartilaginous yang rumit dan sangat khusus antara rotator cuff dan tulang tidak beregenerasi setelah perbaikan. Tendon standar untuk teknik perbaikan tulang hanya mencapai jaringan parut fibrovaskuler yang memiliki sifat mekanik yang relatif buruk. ${ }^{14,15}$ Fokus penelitian terbaru sekarang telah berubah kepada perbaikan lingkungan biologis di sekitar sel tersebut. Stem cell telah menunjukkan potensi besar dalam meningkatkan proses penyembuhan biologis berdasarkan pengaruhnya dalam angiogenesis dan pola inflamasi. $^{13,16}$

Sesuai dengan laporan Ellera Gomes et al yang menerbitkan karya mereka pada 14 pasien dengan robekan rotator cuff lengkap yang diperbaiki dengan cara transosseous melalui sayatan mini yang menambah jahitan dengan sel-sel induk mononuklear dari aspirasi sumsum tulang iliaka. ${ }^{17-18}$

Isaac juga menambahkan terapi stem cell lanjutan dan terapi gen merupakan pilihan yang paling layak untuk meningkatkan penyembuhan rotator cuff. Pengetahuan yang lebih baik tentang fase molekuler embriogenesis enthesis serta 
cedera dan pola penyembuhan telah memungkinkan untuk mengidentifikasi faktor pertumbuhan dan protein yang ditargetkan. ${ }^{12,19}$

Hal ini juga didukung pada penelitian Oh et al yang melaporkan pada model rotator cuff menggunakan AMSC menghasilkan peningkatan kapasitas regenerasi dan percepatan dari penyembuhan setelah infiltrasi dari jaringan stem cell lemak pada otot. ${ }^{20}$

Hasil rata-rata menunjukkan adanya hasil yang lebih baik pada kelompok dengan penambahan amniotic membrane dan mesenchymal stem cell dibanding pada kelompok supraspinatus reparation saja. Terdapat 2 evaluasi tidak signifikan pada flexion score dan lateral elevation $\left(\mathrm{p}_{\text {flexion }}=\right.$ 0,301; plateral elevation $=0,114$ ) yang dapat disebabkan karena kurangnya jumlah sampel dan tidak adanya kontrol pada penelitian ini.

\section{KESIMPULAN DAN SARAN}

\section{Pain score, ADL score, external rotation} score, dan internal rotation score pada kelompok dengan penambahan amniotic membrane dan mesenchymal stem cell secara signifikan lebih baik daripada kelompok dengan penambahan tersebut.

2. Flexion score dan lateral elevation score pada kelompok dengan penambahan amniotic membrane dan mesenchymal stem cell tidak secara signifikan lebih baik daripada kelompok dengan penambahan tersebut.

3. Pendekatan rekayasa jaringan pada reparasi supraspinatus akan meningkatkan pemulihan fungsional. Augmentasi menggunakan membran amnion komposit dan sel induk mesogenymal allogenic pada reparasi supraspinatus telah menghasilkan hasil fungsional yang lebih baik.

4. Pada penelitian ini didapatkan distribusi data tidak normal pada masing-masing variabel $\quad(p<0,005)$. Peneliti telah mencoba memperbesar jumlah sample dan mengurangi nilai ekstrim namun terkendala keterbatasan data sehingga uji non parametrik yang digunakan adalah Mann-Whitney. Kelemahan data non parametrik adalah penelitian ini tidak mewakili data di populasi atau tidak mewakili keadaan di populasi.

Saran dari penelitian ini sebaiknya menggunakan sampel dengan jumlah yang lebih banyak dan kohort prospektif atau eksperimental dengan randomisasi.

\section{REFERENSI}

1. Bianchi S, Martinoli C. Ultrasound of The Musculoskeletal System: Shoulder. 2007; Springer-Verlag 190e331.

2. M Precerutti, E Garioni, L Madonia, F Draghi. US Anatomy of the Shoulder: 
Pictorial Essay. Journal of Ultrasound. 2010; 13, 179e187.

3. Oliva F, Osti L, Padulo J, Maffulli N. Epidemiology of The Rotator Cuff Tears: A New Incidence Related to Thyroid Disease. Muscles Ligaments Tendons J. 2014;4(3):309-14. eCollection 2014.

4. Constant CR, Murley AHG. A Clinical Method of Functional Assessment of the Shoulder. Clin Orthop 1987; 214:160-4.

5. Yin B, Vella J, Levine WN. Arthroscopic Alphabet Soup: Recognition of Normal, Normal Variants, And Pathology. 2010; Orthop Clin North Am Jul;41(3):297e308.

6. Bishop J, Klepps S, Lo IK, Bird J, Gladstone JN, Flatow EL. Cuff Integrity After Arthroscopic Versus Open Rotator Cuff Repair: A Prospective Study. J Shoulder Elbow Surg. 2006; 15:290-9.

7. Galatz LM, Griggs S, Cameron BD, Iannotti JP. Prospective Longitudinal Analysis of Postoperative Shoulder Function: A Ten-Year Follow-Up Study of Full-Thickness Rotator Cuff Tears. $J$ Bone Joint Surg Am. 2001; 83:1052-6.

8. Kim SH, Chung SW, Oh JH. Expression of Insulin-Like Growth Factor Type 1 Receptor and Myosin Heavy Chain in Rabbit's Rotator Cuff Muscle After Injection of Adipose-Derived Stem Cell. Knee Surg Sports Traumatol Arthrosc 2014;22(11):2867-73.

9. Plate JF, Brown PJ, Walters J, Clark JA, Smith TL, Freehill MT, et al. Advanced Age Diminishes Tendon-To-Bone Healing in A Rat Model of Rotator Cuff Repair. Am J Sports Med. 2014; 42:859-68.

10. Ilija Ban, Anders Troelsen, David Høyrup Christiansen, Susanne Wulff Svendsen \& Morten Tange Kristensen. Standardized Test Protocol (Constant Score) for Evaluation of Functionality in Patients with Shoulder Disorders. Dan Med J. 2013;60(4):A4608.

11. Pilar Tornero-Esteban, José Antonio Hoyas, Esther Villafuertes, Cruz
Rodríguez-Bobada, Yamila LópezGordillo, Francisco J. Rojo, et al. Efficacy of Supraspinatus Tendon Repair Using Mesenchymal Stem Cells Along with A Collagen I Scaffold. Journal of Orthopaedic Surgery and Research. 2015;10:124.

12. Nourissat G, Diop A, Maurel N, Salvat C, Dumont S, Pigenet A, et al. Mesenchymal Stem Cell Therapy Regenerates the Native Bone-Tendon Junction After Surgical Repair in A Degenerative Rat Model. PLoS One. 2010;5:e12248.

13. Manning CN, Kim HM, SakiyamaElbert S, Galatz LM, Havlioglu N, Thomopoulos S. Sustained Delivery of Transforming Growth Factor Beta Three Enhances Tendon-To-Bone Healing in A Rat Model. J Orthop Res. 2011; 29:1099-105.

14. Santoni BG, McGilvray KC, Lyons AS, Bansal M, Turner AS, Macgillivray JD, et al. Biomechanical Analysis of an Ovine Rotator Cuff Repair Via Porous Patch Augmentation in A Chronic Rupture Model. Am J Sports Med. 2010; 38:679-86.

15. Yamamoto A, Takagishi K. The Impact of Faulty Posture on Rotator Cuff Tears with and without Symptoms. J Shoulder Elb Surg. 2014; 1-7.

16. Ariyando; I, Suroto H, Roeshadi D. Antara Ekspresi TGF- $\beta$ pada Proses Penyembuhan Reparasi Ruptur Tendon Achilles dengan dan Tanpa Pemberian Sel Punca Mesensimal Sumsum Tulang. Journal Orthopaedi and Traumatology Surabaya. 2012;1(1):1-7.

17. Longo UG, Lamberti A, Petrillo S, Maffulli N, Denaro V. Scaffolds in Tendon Tissue Engineering. Stem Cells Int. 2012; 2012:517165.

18. Ellera Gomes JL, da Silva RC, Silla LM, Abreu MR, Pellanda R. Conventional Rotator Cuff Repair Complemented by The Aid of Mononuclear Autologous Stem Cells. Knee Surg Sports Traumatol Arthroscop 2012;20(2):373-7. 
19. Isaac C, Gharaibeh B, Witt $M$, Wright VJ, Huard J. Biologic Approaches to Enhance Rotator Cuff Healing After Injury. J Shoulder Elb Surg. 2012; 21(2):181-190.

20. Joo Han Oh, Bong Jae Jun, Michelle H McGarry, Thay Q Lee. Surgery IS, Incorporated IN. Does A Critical Rotator Cuff Tear Stage Exist? 2011; 93a(22):2100-9. 